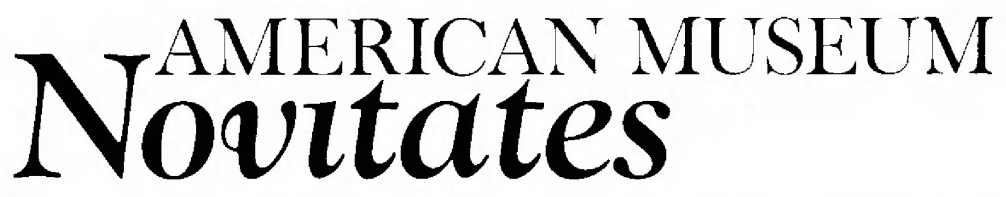

PUBLISHED BY THE AMERICAN MUSEUM OF NATURAL HISTORY CENTRAL PARK WEST AT 79TH STREET, NEW YORK, NY 10024 Number 3316, 15 pp., 6 figures, 1 table January 30, 2001

\title{
Generic Recognition for a Neglected Lineage of South American Pitvipers (Squamata: Viperidae: Crotalinae), with the Description of a New Species from the Colombian Chocó
} RONALD L. GUTBERLET, JR. ${ }^{1}$ AND JONATHAN A. CAMPBELL ${ }^{2}$

\section{CONTENTS}

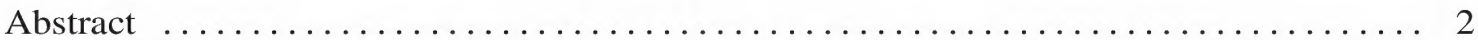

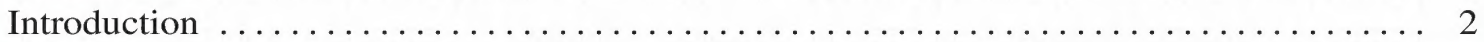

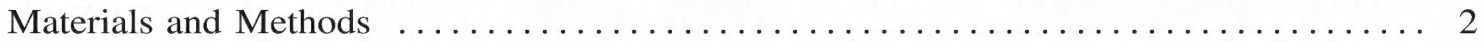

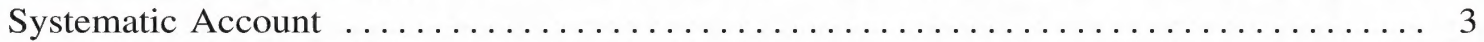

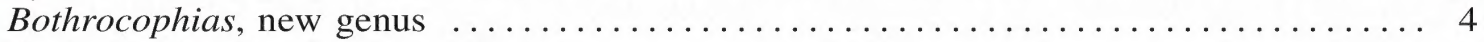

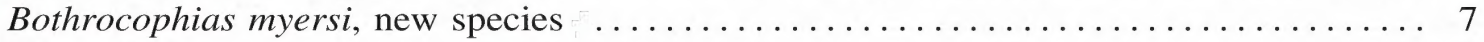

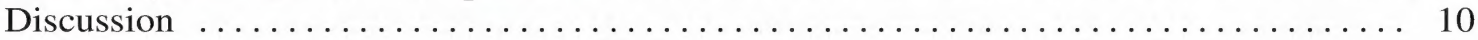

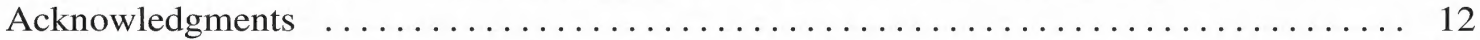

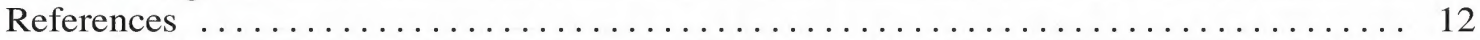

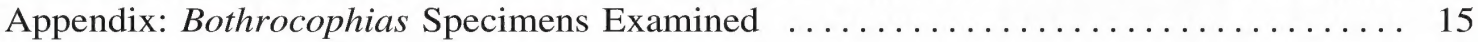

\footnotetext{
${ }^{1}$ Department of Biology, The University of Texas at Tyler, 3900 University Boulevard, Tyler TX 75799.

${ }^{2}$ Research Associate, Division of Vertebrate Zoology (Herpetology), American Museum of Natural History; Department of Biology, Box 19498, The University of Texas at Arlington, Arlington TX 76019.
} 


\begin{abstract}
The name Bothrops campbelli Freire-Lascano (1991) is currently applied to two distinct species. We restrict use of the name campbelli to the species that occurs on the western slopes of the Andes in Ecuador, and we describe the species that occurs in the Chocoan rainforest of western Colombia. Besides B. campbelli, the closest living relatives of the new species appear to be B. hyoprora and B. microphthalmus of the Atlantic slopes and lowlands of northern South America. Together these four species comprise a distinctive clade for which we propose the new generic name Bothrocophias.
\end{abstract}

\section{INTRODUCTION}

The Chocó region of southwestern Colombia and northwestern Ecuador is noted for its heavy rainfall, remarkable biological diversity, and high number of endemic species. During a trip to the Colombian Chocó in 1973, Charles Myers and John Daly collected a series of pitvipers that obviously represents an undescribed species; these specimens were deposited in the American Museum of Natural History (AMNH). Additional material of this species is housed in the Field $\mathrm{Mu}-$ seum of Natural History (FMNH), The University of Texas at Arlington Collection of Vertebrates (UTA), and the United States National Museum (USNM).

Recent treatments of Neotropical pitvipers (e.g., Campbell and Lamar, 1989, 1992) have discussed specimens of the new species together with specimens of Bothrops campbelli Freire-Lascano (1991) under the name Bothrops pulcher (Peters, 1862). Schätti and Kramer (1993) discovered that the holotype of Bothrops pulcher (Peters) actually represents what had been referred to in much of the literature as Bothriopsis albocarinata (Shreve, 1934) and therefore the name pulcher has priority. After receiving several comments and recommendations regarding this taxonomic confusion (Gutberlet and Harvey, 1998; Kuch, 1997; Schätti and Smith, 1997; Wüster, 1998), the International Commission on Zoological Nomenclature (1999) resolved the issue as follows (Opinion, 1939): the correct name for the highland, arboreal pitviper recently known as Bothriopsis albocarinata is Bothriopsis pulchra (Peters), and the snake referred to as Bothrops pulcher by Campbell and Lamar (1989) and many previous workers is now appropriately known as Bothrops campbelli Freire-Lascano. See McDiarmid et al. (1999) for additional comments on this issue.

Herein, we demonstrate that the name Bothrops campbelli applies to a highland species known only from the Pacific slope of the Ecuadorian Andes, and we propose a new name for the lowland species from the Colombian Chocó. Also, in a continuing effort to resolve the paraphyly of the genus Bothrops, we recognize a new genus for a distinctive lineage from northern South America that includes Bothrops campbelli, B. hyopro$r a, B$. microphthalmus, and the new species.

\section{MATERIALS AND METHODS}

Comparative data for diagnosing the new species were obtained through examination of museum specimens (appendix I) and from information provided by Campbell and Lamar (1989, 1992), Freire-Lascano (1991), and Nicéforo-María (1975).

The following features were measured with dial calipers or with a meter stick and string: snout-vent length (SVL), tail length (TL), distance from anteroventral corner of eye to caudal border of pit (EP), distance from anterodorsal corner of eye to center of naris (EN), horizontal distance across eye (ED), distance from tip of snout to angle of jaw (HL), height of rostral taken at midline $(\mathrm{RH})$, width of rostral taken at widest point (RW).

Terminology for most scales follows Klauber (1972). Interoculabials were counted in a vertical line from below the pupil of the eye to the mouth, including one subocular and one supralabial. Prefoveals are the small scales bounded by the supralabials, nasals, loreals, lacunals, and subfoveals (if present). The level of the anterior edge of the pit demarcates the separation between prefoveals and subfoveals. Canthals are the scales along 
the lateral edge of the dorsal surface of the head, and are situated between the internasals and the supraoculars. Canthals are counted in a single row, and the small scales adjacent to the supraoculars are also included in the canthal series, even when these scales are excluded from the canthus rostralis proper by the dorsalmost preocular. This method of counting canthals is the same one used by Gutberlet (1998a) and is consistent with Klauber's (1972) definition. Intersupraoculars are counted in a straight line between the two supraoculars, which are not included in the series. Gulars were counted in a straight line between the chin shields and the first scale on the underside of the head, which is wider than long. Interrictal counts include the last supralabial on each side. Dorsal scale rows were counted one head length behind the occiput, at midbody, and one head length anterior to the vent. The first ventral is considered to be the first scale on the underside of the head that is bordered on both sides by the first row of dorsals (Dowling, 1951). The last ventral is the scale anterior to the anal plate. We use slashes to denote paired structures on the left/right sides of the body. Terminology for hemipenes is that of Dowling and Savage (1960).

The decision to recognize a new genus for the clade we discuss below is based primarily on a suite of shared, derived characters identified in phylogenetic analyses of New World pitviper species (Gutberlet and Harvey, in press; Parkinson et al., in press). All other recent phylogenetic studies of pitvipers, though they do not address the monophyly of the clade in question, have presented hypotheses of pitviper relationships that are consistent with the classification we propose (see Gutberlet, 1998a; Kraus et al., 1996; Parkinson, 1999; Salomão et al., 1997; Vidal and Lecointre, 1998; Vidal et al., 1997; Werman, 1992; Werman et al., 1999). We carefully considered each of these studies in reaching our decision, which we discuss fully below.

\section{SYSTEMATIC ACCOUNT}

As pointed out by Campbell and Lamar (1992), recognition of the distinctive clade of South American arboreal pitvipers as Both- riopsis renders the remaining terrestrial Bothrops paraphyletic. Including the species of Bothriopsis in the genus Bothrops, as suggested by Salomão et al. (1997), would at least partially rectify this problem. An alternative is to partition the large and unwieldy genus Bothrops, as currently recognized, into several genera and continue to recognize Bothriopsis (Campbell and Lamar, 1992; McDiarmid et al., 1999). We prefer the latter approach, which allows continued recognition of the distinctive Bothriopsis clade and which will in our opinion better describe the evolutionary history of South American pitvipers.

In phylogenetic analyses using characters from gross anatomy, Gutberlet and Harvey (in press) identified a clade that includes Bothrops campbelli, B. microphthalmus, and $B$. hyoprora. This group was recovered in every analysis with bootstrap support ranging between 75 and $100 \%$. In a separate study based on mitochondrial DNA evidence (Parkinson et al., in press), the sister relationship of B. hyoprora and B. microphthalmus was strongly supported; $B$. campbelli was not included in that study. A fourth species, which we describe below, shares several unique derived character states with these species, indicating that it is part of this clade.

Could this monophyletic group be accommodated within an existing genus? Though the clade was recovered in every analysis conducted by Gutberlet and Harvey (in press), its position relative to other South American lineages varied among analyses (fig. 1). Seven of eight analyses indicated that the B. hyoprora clade is more closely related to Lachesis than it is to Bothrops + Bothriopsis. If this hypothesis of relationships is accurate, a new generic name for the hyoprora clade is needed to rectify the paraphyly of Bothrops, regardless of how the species of Bothriopsis are treated. One of eight analyses indicated that the hyoprora clade is sister to Bothrops + Bothriopsis and that Lachesis falls outside this clade. In every analysis conducted by Parkinson et al. (in press), the hyoprora clade was found to be sister to Bothrops + Bothriopsis. Thus, even if the species of Bothriopsis were to be included in Bothrops, the generic partition we 


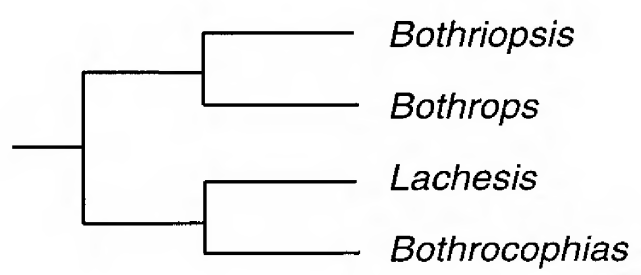

A

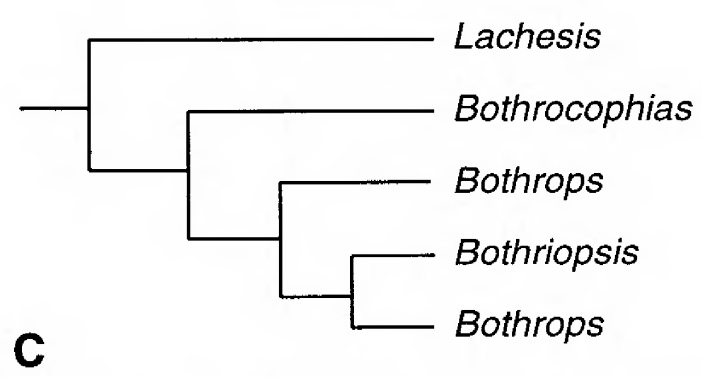

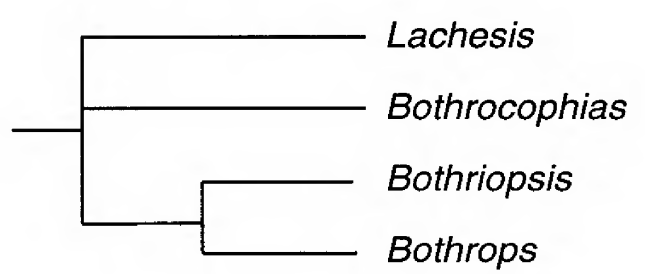

B

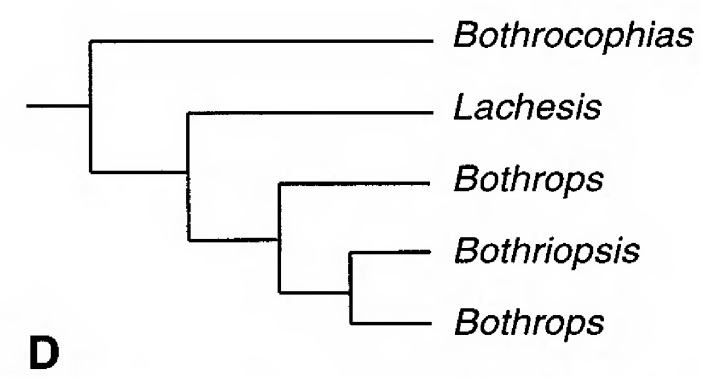

Fig. 1. Alternative hypotheses of relationships among species of Bothrops, Bothriopsis, Lachesis, and Bothrocophias new genus. (A) Recovered in six of eight different analyses of anatomical data only (Gutberlet and Harvey, in press); (B) recovered in one reanalysis of Kraus et al.'s ND4 sequence data (Gutberlet, 1998b); (C) recovered in one of eight analyses of anatomical data only (Gutberlet and Harvey, in press) and in all analyses of sequence data from four mitochondrial genes (Parkinson et al., in press); (D) recovered in one of eight analyses of anatomical data only (Gutberlet and Harvey, in press).

propose represents progress toward a natural classification of New World pitvipers.

\section{Bothrocophias, new genus}

TYPE SPECIES: Bothrops hyoprorus Amaral (1935), by present designation.

ETYMOLOGY: The generic name is derived from the Greek words bothros, meaning pit, and kophias, meaning snake or adder; the gender of this name is masculine.

CONTENT: The genus Bothrocophias contains four species: campbelli known only from the western slopes of the Ecuadorian Andes; hyoprora distributed throughout the western lowlands of the Amazonian rainforest; microphthalmus, found along the eastern versant of the Andes in Colombia, Ecuador, Peru, and possibly Bolivia; and a new species described below that is restricted to lowland rainforest in western Colombia (fig. 2).

Definition And Diagnosis: A lineage of crotaline snakes occurring in northern South
America. Members of the four species included in this lineage are of moderate length, relatively stout-bodied, and terrestrial, lacking a prehensile tail. Females attain greater size than do males. The snout is weakly ( $B$. campbelli and the new species described subsequently in this paper) to strongly ( $B$. hyoprora and B. microphthalmus) elevated with a rostral scale that is approximately as high as broad or distinctly higher than broad. Dorsal coloration within the genus consists mainly of darker shades of brown and reddish-brown. A pattern of dorsal banding may be clearly evident or subdued, and in some specimens the bands do not meet evenly at the middorsal line and are staggered as large lateral blotches.

Derived characteristics shared by the four species of Bothrocophias include small, smooth intersupraocular scales; distinctive white spots on gular and infralabial scales; and tuberculate keels on scales on the caudal portion of the dorsum. Many, though not all, 


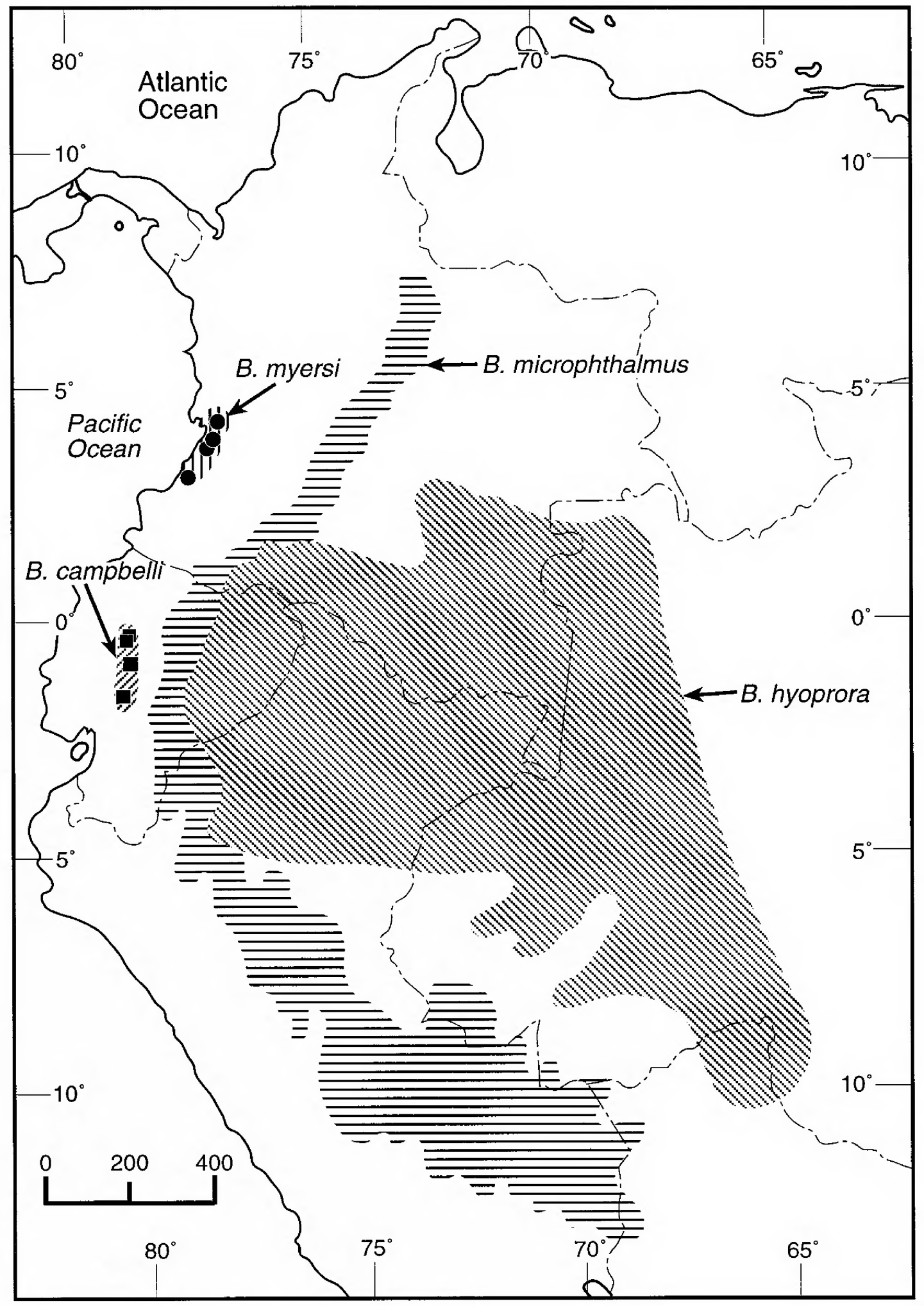


specimens of B. hyoprora and B. microphthalmus exhibit tiny scales between the rostral and internasals that have not been observed in any other New World pitviper.

There are 124-177 ventrals; 38-64 subcaudals, most of which are entire in $B$. hyoprora, but mostly divided in the other three species; 21-25 middorsal scale rows; 2-9 smooth intersupraoculars; 7-8 supralabials; 8-11 infralabials; $1-11$ prefoveals; $1-3$ canthals; and 3-4 interoculabials.

The osteology of the genus remains poorly known, though we have been able to examine one skull each of Bothrocophias hyopro$r a$ and B. microphthalmus. In these two species, the dorsal surface of the frontal bones is predominantly flat. The postfrontals are large, contributing more to the dorsal perimeter of the orbit than does the parietal. The posterolateral edges of the dorsal surface of the parietal bear a small lateral shelf of bone. The ectopterygoid has a single pit for the attachment of the ectopterygoid retractor muscle, is approximately equal in length to the base of the pterygoid, and has a broad, flat shaft. The choanal process is positioned medially on the palatine bone and is attenuate distally. The angular and splenial are partially fused, and the Meckellian foramen is divided by a thin extension of bone. Species of Bothrocophias have 4-5 palatine teeth, 1215 pterygoid teeth, and 14-16 dentary teeth. The maxillary fang is approximately 1.5 times longer than the height of the maxilla.

We have seen hemipenes of Bothrocophias hyoprora and the species described in this paper. Hemipenes of these species are calyculate distally. Walls of the more proximal calyces are spinulate. Proximal to the calyces, small mesial spines and a moderate number (ca. 18-30 per lobe) of lateral spines are present. Though some lateral spines are noticeably larger than the mesial spines, none can be characterized as basal hooks. The hemipenes of $B$. hyoprora differ slightly from those of the new species in having longer and more slender lateral spines.

The following combination of characters diagnoses Bothrocophias from all other New World pitviper genera: (1) 7-8 supralabials; (2) small but unkeeled dorsal head scales, not arranged in a nine-plate, colubrid-like pattern; (3) tubercular keels on dorsal scales on posterior half of body; (4) white spots with dark borders on some gulars and infralabials; (5) 124-177 ventrals; (6) 4-5 palatine teeth; (7) 12-15 pterygoid teeth; (8) 14-16 dentary teeth; (9) maxillary fang approximately 1.5 times longer than height of maxilla; (10) mesial spines present on hemipenial lobes; (11) moderate number (ca. 18-30 per lobe) of lateral spines on hemipenes; (12) hemipenial lobes only slightly longer than organ's base; (13) choanal process of palatine attenuate distally; (14) ectopterygoid and base of pterygoid approximately equal in length; (15) dorsal surface of frontal bones predominantly flat; (16) postfrontal bones large, contributing more to dorsal perimeter of orbit than does parietal; (17) tail not prehensile and lacks a rattle.

Because the species of Bothrocophias have been previously included in the genus Bothrops, it is significant that skull morphology in the two genera is markedly different. In Bothrops (sensu stricto), including such species as $B$. asper and $B$. atrox, the skull is relatively narrow and elongate (Werman, 1992, 1999; Gutberlet, 1998a; Gutberlet and Harvey, in press), whereas the skull in Bothrocophias species is broad and heavily ossified. Specific characteristics that typify this divergence in skull morphology are (condition of Bothrops in parentheses): distance across frontals equal to (less than) width of skull at anterior end of supratemporals, shaft of ectopterygoid wide and flat (slender and round in cross section), and shaft of ectopterygoid equal to (greater than) length of base of pterygoid.

The holotype of Bothrocophias campbelli (INHMT 1956) is from Provincia de Chimborazo, Ecuador. As Campbell and Lamar (1992) noted, all specimens from Colombia previously assigned to $B$. campbelli possess a lower number of ventrals and coloration

$\leftarrow$

Fig. 2. Map of northwestern South America, showing geographic distribution of species of Bothrocophias. Ranges of B. hyoprora and B. microphthalmus are based on Campbell and Lamar (1989). 
different from those from further south. These differences, in addition to others listed below, clearly indicate that the Colombian snakes represent a distinct species, and this may be known as

\section{Bothrocophias myersi, new species}

Botrops lanceolatus-García, 1896: 22 [not of Bonnaterre, 1790; placement of this name here is tentative].

Bothrops pulcher [not of Peters, 1862]-PérezSantos and Moreno, 1988: 358 [in part, also included undetermined taxa from Amazonian forests of Ecuador, Peru, and Colombia]; Campbell and Lamar, 1989: 221 [in part, included B. campbelli]; Campbell and Lamar, 1992: 11 [in part, included B. campbelli]; Vázquez de Kartzow, 1995: 86.

Porthidium almawebi Schätti and Kramer, 1993: 258. Holotype: MHNG 2248.12. Type locality: 'San Francisco de las Pampas $\left(0^{\circ} 26^{\prime} \mathrm{S}\right.$ x $78^{\circ} 57^{\prime}$ W, Cotopaxi, ca. 1'800 m ü M.)" [In part, included $B$. campbelli].

Porthidium almawebi-Golay et al., 1993: 83 [in part, included $B$. campbelli].

Bothrops campbelli-McDiarmid et al., 1999: 259 [in part, included B. campbelli].

Holotype: American Museum of Natural History (AMNH) 109812 (original field number CWM 11878); an adult female (figs. 3, 4) from Quebrada Guanguí, $0.5 \mathrm{~km}$ above the Río Patia, Department of Cauca, Colombia, 100-200 m, collected by C. W. Myers and J. W. Daly, 16-17 February 1973.

PARATYPES: All from Colombia: Cauca: Quebrada Guanguí, ca. $0.5 \mathrm{~km}$ above the Río Patia, 100-200 m (AMNH 107919-20); Valle del Cauca: Pacific coast on road Buenaventura-Río Calima (FMNH 165586-96); Caimancito, $\mathrm{S}$ of Buenaventura, on bank of Río Cajambre, 75 m (UTA R-21689); Buenaventura, near Río Raposo (USNM 151708, 154051).

DiAGNOSIS: A moderately stout, terrestrial pitviper reaching a maximum known total length of $756 \mathrm{~mm}$ that may be distinguished from all other New World rattleless pitvipers by the following combination of characters: (1) 139-151 ventrals; (2) 44-52 divided subcaudals; (3) 21-23 dorsal scale rows at midbody; (4) prelacunal fused with second supralabial; (5) 3-6 smooth intersupraoculars; (6) 7 supralabials; (7) reddish-brown dorsal coloration in life; (8) distinctive white spots on some gular and infralabial scales.

COMPARISONS: Bothrocophias myersi and $B$. campbelli are easily distinguished from their Amazonian congeners by the presence of a lacunolabial (prelacunal not fused to second supralabial in $B$. microphthalmus and $B$. hyoprora). Additionally, $B$. hyoprora is the only member of the genus with undivided subcaudals. Bothrocophias myersi differs from $B$. campbelli in having fewer ventrals (139-151 vs. 162-177), fewer subcaudals (44-52 vs. 48-64), fewer intersupraoculars (3-6 vs. 6-8), and fewer prefoveals (1-2 vs 2-4). All known specimens of B. myersi except one (UTA R-21689, a small specimen with a banded pattern) have a distinctive brown-bronze dorsum in preservative, which differs from the distinctly banded dorsum of juvenile and adult $B$. campbelli. Because the holotype of $B$. myersi was reddish-brown in life and is now brown-bronze in preservative, we presume that all the brown-bronze specimens were reddish-brown in life. Table 1 summarizes additional variation among the four species of Bothrocophias.

Bothrocophias myersi is potentially sympatric with five pitviper species: Bothriechis schlegelii, Bothriopsis punctata, Bothrops asper, Lachesis stenophrys, and Porthidium nasutum (Campbell and Lamar, 1989; Zamudio and Greene, 1997). Bothriechis schlegelii and Bothriopsis punctata have prehensile tails (tail not prehensile in B. myersi). Also, B. schlegelii has undivided subcaudals and spinelike superciliary scales, and $B$. punctata has many more ventrals (175-213) than does B. myersi. Bothrops asper and Lachesis stenophrys attain considerably greater lengths and also have higher ventral scale counts (161-240 and $>199$, respective1y). The twice-divided distal subcaudals of Lachesis are unique to that genus. Porthidium nasutum bears 24-41 undivided subcaudals, lacks a lacunolabial, has a rostral scale that is markedly higher than broad, and has fewer ventrals (123-145).

DESCRIPTION OF HOLOTYPE: An adult female; rostral almost rectangular, but slightly wider ventrally, almost as wide as high (4.2 $\times 4.3 \mathrm{~mm}$ ); nasal incompletely divided above naris, distinctly divided below naris; loreal single, bordered anterodorsally by 


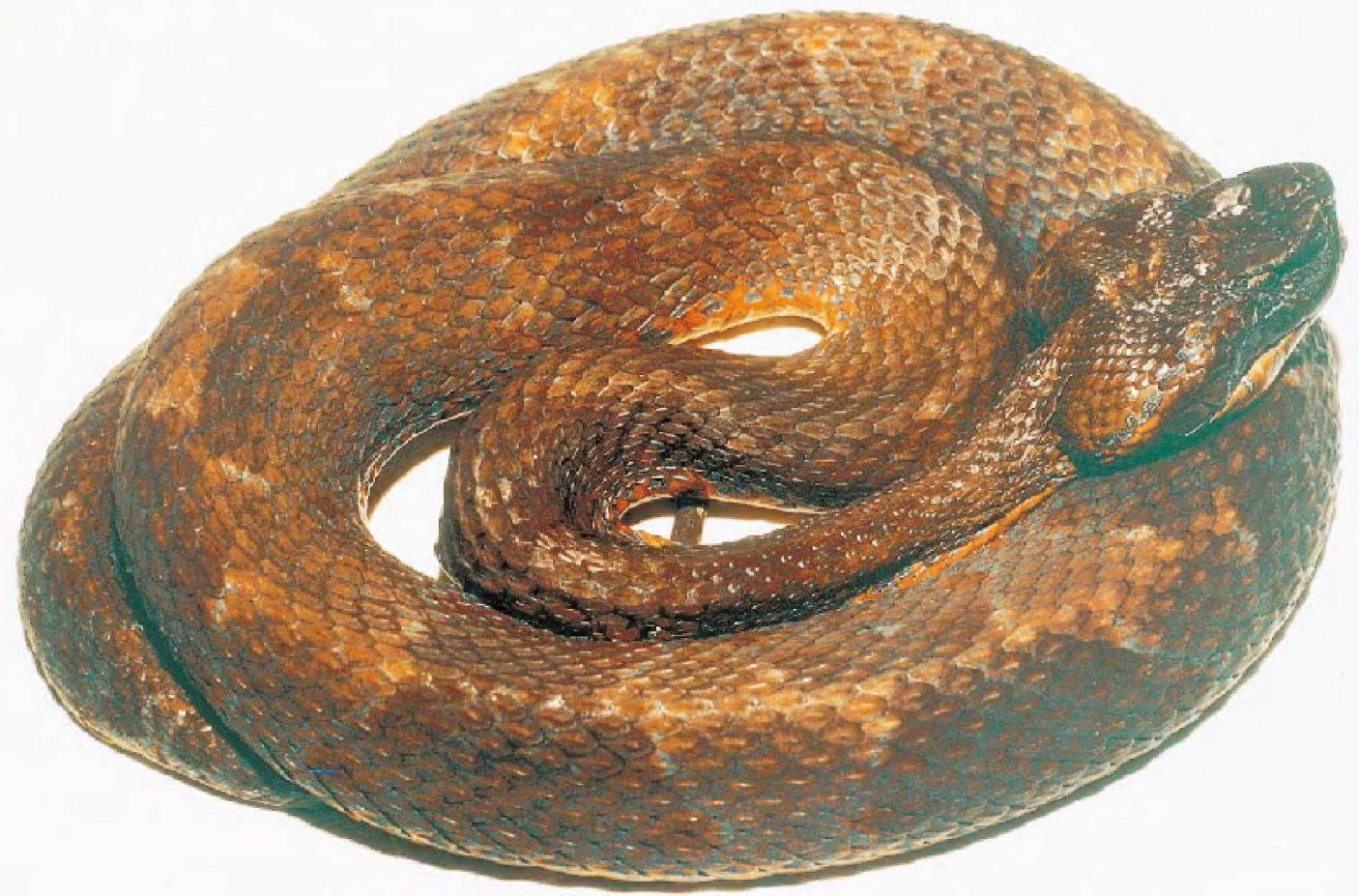

Fig. 3. Bothrocophias myersi, holotype (AMNH 109812), $756 \mathrm{~mm}$ total length.

larger canthal and by upper preocular posteriorly, longer than high; prefoveals $2 / 2$; subfoveals absent; prelacunal fused to second supralabial; interoculabials $3 / 3$; postfoveals $1 / 1$, longer than high, extending posteriorly beyond posteroventral corner of pit, contacting lower preocular posteriorly and lacunolabial anteriorly; preoculars 3/3; upper preocular longer than high, contributing to canthus; middle preocular much shorter, contacting but not fused to supralacunal; lower preocular tiny, almost excluded from orbit by subocular and middle preocular; suboculars $1 / 1$, each partially divided anteriorly; postoculars $2 / 2$; supralabials $7 / 7$; infralabials $9 / 9$, first infralabial on left side partially fused to mental, first pair of infralabials barely contact each other medially; mental approximately as wide as long; chin shields longer than wide, contacting first four infralabials on each side; gulars between chin shields and first scale on underside of head that is wider than long $4 / 5 ; 4$ internasals, middle two smallest and partially fused medially; canthals $2 / 2$, anterior canthal distinctly larger, posterior canthal tiny, separating anterior canthal from supraocular; intercanthals 3, immediately posterior to internasals; intercanthals 5, between posterior canthals; intersupraoculars 6; all dorsal head scales, from level of posterior of supraoculars forward, smooth; supraoculars longer than wide but distinctly wider than adjacent intersupraoculars; dorsal scale rows 25-23-19; ventrals 148 , ultimate scale in series extending only partially across venter; anal entire; subcaudals 48, all divided; tail spine slightly compressed laterally, curving slightly dorsad, as long as adjacent 3 subcaudals, tip blunt; dorsals extending onto tail spine only slightly farther than subcaudals; dorsal scales of middorsum at midbody twice as long as wide anteriorly, becoming wider posteriorly such that length only slightly exceeds width; dorsal body scales distinctly keeled, keel does not extend to terminus of scale, keels distinctly tuberculate on posterior portion of body; paraventrals smooth over most of body, very weakly keeled posteriorly, similar in size and shape to adjacent dorsals; para- 


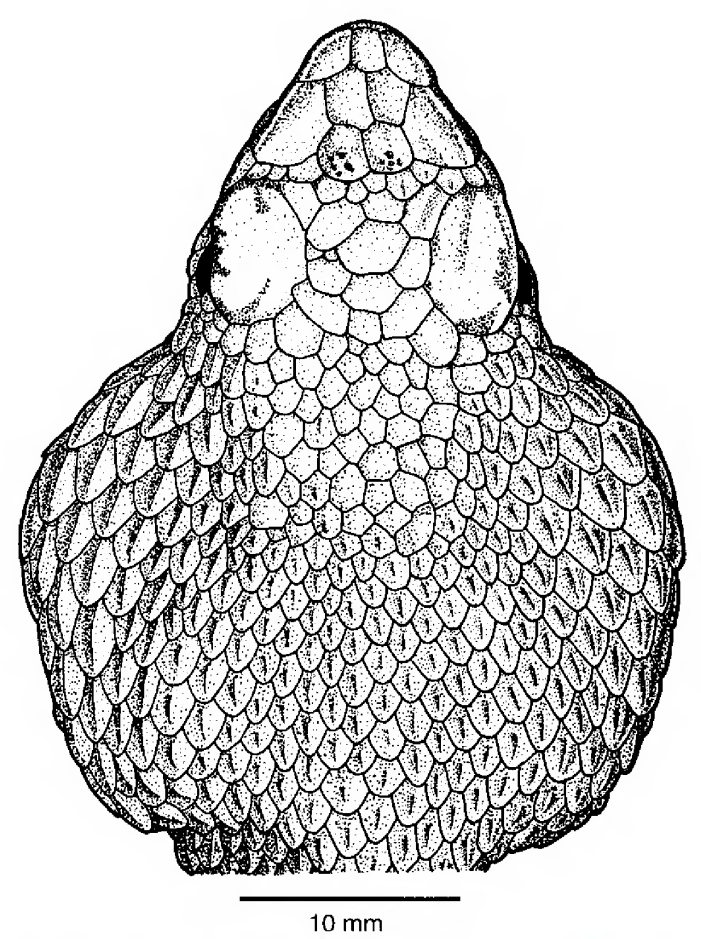

Fig. 4. Bothrocophias myersi, paratype (FMNH 165593), dorsal view of head, head length $35 \mathrm{~mm}$.

subcaudals weakly keeled anteriorly, smooth posteriorly.

Measurements of holotype (in millimeters): SVL 597, TL 92, EP 1.7, EN 6.7, ED 3.9, HL 30.1, RH 4.3, RW 4.2.

In his field notes, Myers described the color in life of the holotype as follows: "Dark red-brown, posteriorly turning light bluegray on sides. Pale grayish blue oblique lines from eye, and small spots of same color underneath head. Under head and venter orange, except turning white down center on posterior half of belly." From our inspection of color slides of the holotype (AMNH 109812) taken before preservation, we can add the following: the dorsal coloration is almost uniform, but slightly darker bands are discernible against the red-brown ground color (fig. 3). From the supraoculars forward, the top of the head is dark brown, as is most of the side of the head. The iris appears to be red-brown, paler above.

Color in preservative ( $70 \%$ ethanol after $10 \%$ formalin): Dorsal surface of head un- patterned, pale brown to bronze in color; a wide, pale, brown-bronze postocular stripe extending from the posteroventral corner of eye to cover supralabial 7 , all but anteroventral corner of supralabial 6 , and posterodorsal edge of supralabial 5; pale postocular stripe bordered dorsally by a thin, dark brown stripe, and anteroventrally by a thicker stripe of same dark brown color; most of side of head and rostral dark brown, but with a small triangle of pale brown-bronze occupying anteroventral corner of supralabial 4 and posteroventral corner of supralabial 3; dorsum brown-bronze with a greater amount of dark brown or dark gray coloration laterally; most paraventrals partly dark graybrown and partly cream-colored; no clear pattern discernible on dorsum; tail plain brown dorsally, darker than dorsal body coloration; ventral scales predominantly cream but also with a small amount of brown pigment, mostly concentrated laterally; subcaudals also cream but with slightly more brown pigment than ventrals; ventral surface of head cream but with distinctive coloration on several scales; mental and first 2 infralabials on each side dark brown; 5 infralabials on each side and a total of 8 gular scales containing white spots with irregular dark brown edges.

VARIATION: On each side of the head, specimens of Bothrocophias myersi have 12 prefoveals, 1-2 canthals, 3-4 interoculabials, 1 postfoveal, 3 preoculars, 1-3 suboculars, 1-2 postoculars, 7 supralabials, 8-10 infralabials, and 3-5 gulars between the chin shield and first ventral. Additional variation in features of scalation includes 3-4 internasals, 2-3 anterior intercanthals, 4-7 posterior intercanthals, 3-6 intersupraoculars (fig. 4), 21-26 anterior dorsal scale rows, 2123 middorsal scale rows, 16-19 posterior dorsal scale rows, 139-151 ventrals, and 4452 divided subcaudals. Coloration is similar in all type specimens, with the exception of one small male (UTA R-21689) with fairly distinct bands on the dorsum. Measurements (in millimeters) for specimens in the type series vary as follows. Males: total length 376677, SVL 311-577, tail length 48-100. Females: total length 327-756, SVL 280-655, tail length 47-120. Table 1 summarizes variation within $B$. myersi. 
HEMIPENES: One paratype of Bothrocophias myersi (UTA R-21689) was preserved with its hemipenes everted. The total length of the right hemipenis is equivalent to the length of the first five subcaudals. The lobes bifurcate at a length of two subcaudals from the base, and the sulcus spermaticus divides at a distance approximately one subcaudal from the base. As in most other crotalines, the organ is spinous proximally and calyculate distally. There are 18-20 lateral spines per lobe, including 6-8 that are relatively large (approximately 1 subcaudal in length). Small mesial spines are also present on the proximal half of each lobe. The mesial spines extend as far distally as the lateral spines. The distal half of each lobe is entirely calyculate. Many of the proximal calyces have spinulate walls, but walls of the more distal calyces are smooth.

Distribution AND Habitat: Bothrocophias myersi is known only from the Pacific lowlands (ca. 75-200 m) of Cauca and Valle del Cauca, Colombia. The original habitat in this region consists of very wet rainforest (probably $>5000 \mathrm{~mm}$ of rain per year). Myers et al. (1978: 321-324) provided a detailed description and photographs of the habitat at the type locality. This type of habitat formerly occupied lowland areas of southwestern Colombia and adjacent areas in northwestern Ecuador. It is possible that $B$. myersi occurs (or used to occur) throughout the Chocó region, although we know of no records of this species from Ecuador. Unfortunately, extensive habitat destruction throughout the Ecuadorian Chocó region makes it unlikely that B. myersi currently occurs in that country.

ETyMology: The specific epithet, a noun in the genitive case, is a patronym in honor of Dr. Charles W. Myers, who collected the new species and who has made many significant contributions to Neotropical herpetology through dedicated work in both the field and laboratory.

\section{DISCUSSION}

The two species of Bothrocophias that occur on the Amazonian side of the Andes share several derived character states that are not found in the species west of the Andes (table 1). Bothrocophias hyoprora and B. microphthalmus do not have lacunolabial scales; rather, in these species the prelacunal and the second supralabial are discrete scales that are separated either by a suture or by tiny subfoveal scales. In many, but not all, specimens of $B$. hyoprora and B. microphthalmus, tiny scales are present between the rostral scale and the internasals-canthals (fig. 5). These unusual scales have not been reported in any other New World pitviper species and are here termed "canthorostrals." Canthorostrals do not seem to be homologous with the small scales separating the rostral and prenasal (nasorostrals) that are found in some populations of Atropoides nummifer (Burger, 1950; Werman, 1984). The synapomorphy of canthorostrals strongly suggests that the two eastern species are sister taxa, but available data do not allow resolution of the branching sequence of the two western species (fig. 6).

The phylogenetic evidence suggests that speciation in Bothrocophias may have been precipitated when formation of the Andes isolated the Chocoan rainforest from the Amazonian rainforest, resulting in a geographic barrier to gene flow between eastern and western populations of the common ancestor of this clade. This is consistent with Dixon's (1979) hypothesis that the Chocoan and Amazonian rainforests were connected until the Upper Pliocene, when the Huancabama Deflection was closed by uplifting in the southern Andes. Speciation within the eastern and western components of this clade may have been the result of elevational segregation: $B$. microphthalmus and B. campbelli are upland species, whereas $B$. hyoprora and $B$. myersi are lowland species (fig. 2, table 1).

The identification of monophyletic groups within the large radiation of New World pitvipers has proceeded steadily in recent years (Campbell and Lamar, 1989, 1992; Crother et al., 1992; Werman, 1992; Gutberlet, 1998a). However, relationships among these monophyletic groups have been less tractable: intergeneric relationships among New World pitvipers are largely unresolved. Compare, for example, the findings of Werman (1992), Kraus et al. (1996), and Parkinson (1999). Whereas Werman's analysis identified Ophryacus as sister to Bothriechis, Par- 
TABLE 1

Comparison of Selected Features of Species of Bothrocophias

\begin{tabular}{lcccc}
\hline \hline Feature & B. campbelli & B. hyoprora & B. microphthalmus & $B$. myersi \\
\hline Ventrals & $162-177$ & $124-141$ & $137-168$ & $139-151$ \\
Subcaudals & $48-64$, divided & $38-57$, undivided & $44-59$, divided & $44-52$, divided \\
Dorsal scale rows & $21-25 / 21-25 / 19$ & $23-25 / 21-25 / 19-20$ & $25-27 / 21-23 / 18-19$ & $21-26 / 21-23 / 16-19$ \\
Lacunolabial & present & absent & absent & present \\
Intersupraoculars & $5-8$ & $2-9$ & $4-8$ & $3-6$ \\
Supralabials & $7-8$ & $7-8$ & $7-8$ & 7 \\
Infralabials & $9-10$ & $8-11$ & $8-11$ & $8-10$ \\
Prefoveals & $2-4$ & $3-11$ & $1-4$ & $1-2$ \\
Canthals & $2-3$ & $2-3$ & 2 & $1-2$ \\
Interoculabials & $3-4$ & $3-4$ & $3-4$ & $3-4$ \\
Canthorostrals & absent & often present & often present & absent \\
Elev. distribution & $1300-2000 \mathrm{~m}$ & $0-1000 \mathrm{~m}$ & $1000-2350 \mathrm{~m}$ & $75-200 \mathrm{~m}$ \\
\hline
\end{tabular}

kinson's study suggested that Ophryacus represents the most basal lineage within the Neotropical radiation. Werman's data suggested that Bothrops and Porthidium are sister lineages, but analyses by Kraus et al. and Parkinson did not support this relationship. The phylogenetic position of Lachesis is different in all of these studies. Furthermore, in studies that have used the nonparametric bootstrap, support for intergeneric relationships is consistently low (e.g., Gutberlet, 1998a; Parkinson, 1999).

A recent phylogenetic study (Gutberlet and Harvey, in press) tentatively identified three large monophyletic groups of New World pitvipers - a predominantly North American clade (Agkistrodon, Crotalus, Sistrurus), a Middle American clade (Atropoides, Bothriechis, Cerrophidion, Ophryacus, Porthidium), and a South American clade (Bothriopsis, Bothrocophias, Bothrops). The

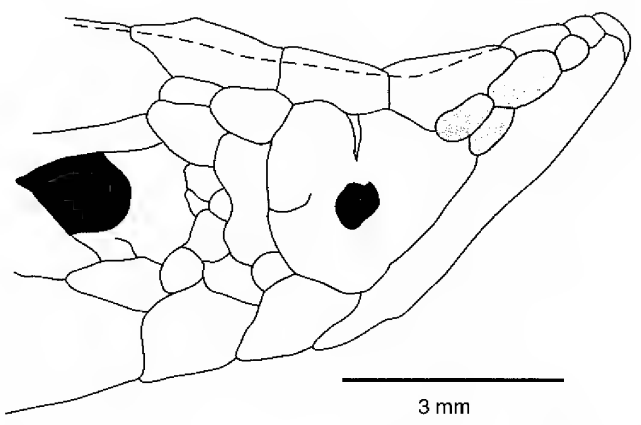

Fig. 5. Lateral view of snout of Bothrocophias hyoprora (FMNH 56171), showing canthorostral scales (shaded).
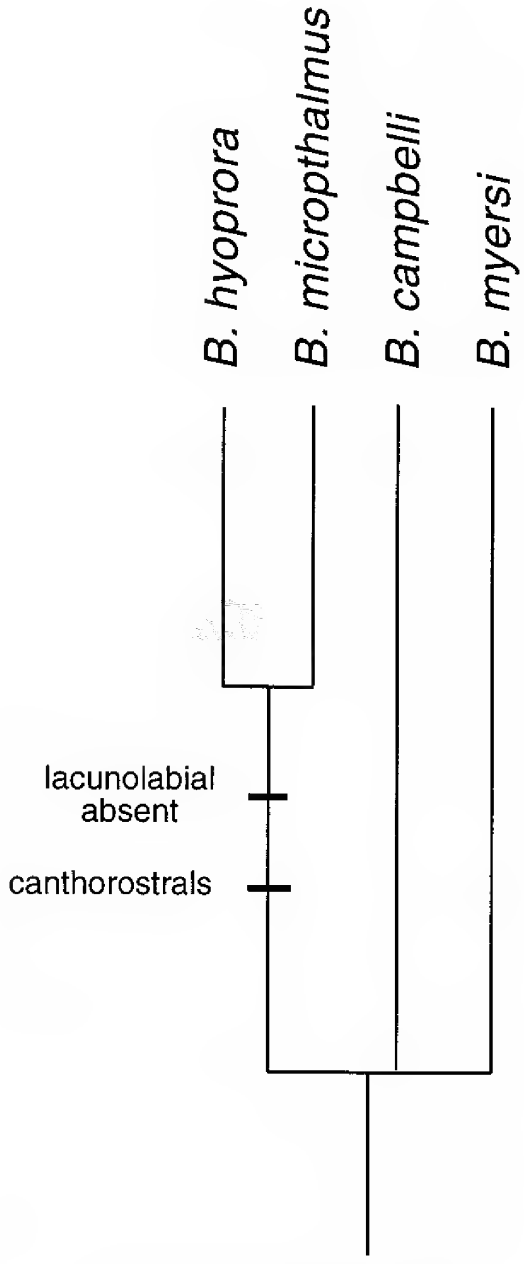

Fig. 6. Hypothesis of relationships for species of Bothrocophias based on parsimony analyses of 76 anatomical characters. 
phylogenetic position of Lachesis is not well resolved. While molecular evidence suggests a Middle American origin for this genus (Parkinson, 1999; Zamudio and Greene, 1997), anatomical evidence suggests that Lachesis may be part of the South American clade (Gutberlet and Harvey, in press). Parkinson (1999) recognized the North American clade as well based on mitochondrial sequence data and his results also supported a monophyletic Neotropical group. We develop this hypothesis slightly further by suggesting that the Middle and South American clades represent sister lineages within the Neotropical group and that the North American clade represents an earlier branch of New World pitviper evolution (the sister group to the Middle and South American clades). Though this hypothesis requires additional testing, we do recognize its intuitive appeal in that it is consistent with a scenario of vicariance-driven evolution within this group.

Available evidence suggests that after the differentiation of these major lineages, some intercontinental dispersal occurred (Bothriechis, Crotalus, Lachesis, and Porthidium into South America from Middle America; Bothrops and Bothriopsis into Middle America from South America). A more detailed picture of the biogeographic history of New World pitvipers awaits further phylogenetic study of this diverse and complex group. For example, the relationship of Bothriopsis relative to other clades of South American pitvipers is in need of additional study. Also, the affinities of the enigmatic Bothrops colombianus and of Lachesis have yet to be resolved satisfactorily.

The progress in Middle American pitviper classification is an excellent example of how fruitful research cycles (sensu Hennig, 1966: 145; Kluge, 1991) can be. We feel that the recognition of Bothrocophias is an important step in the research cycle that will eventually illuminate phylogenetic relationships among all South American pitvipers.

\section{ACKNOWLEDGMENTS}

We are grateful to C. W. Myers who collected much of the material for this new species and generously made available to us his fieldnotes and photographs. For the loan of specimens, provision of working space, or kind hospitality, we thank L. Ford, D. R. Frost, C. W. Myers (AMNH), A. Resetar, H. Voris (FMNH), S. Gotte, R. McDiarmid, J. Poindexter III, R. P. Reynolds, G. Zug (USNM), W. E. Duellman, J. R. Mendelson III, C. Sheil, J. Simmons, L. Trueb (KU), R. Drewes, E. Hekkala, C. Spencer, J. Vindum (CAS), E. Censky, S. Rogers, M. Servedio, and J. J. Wiens (CM). Financial support for RLG was provided by a Stearns Grant-InAid of Herpetological Research from the California Academy of Science, a Carnegie Museum of Natural History Collection Study Grant in Herpetology, and scholarships from the North Texas Herpetological Society. We thank P. T. Chippindale, D. R. Frost, H. W. Greene, and C. L. Parkinson for reviewing earlier drafts of this article.

\section{REFERENCES}

Amaral, A. D.

1935. Estudios sôbre ophídios Neotrópicos. XXXIII. Novas especies de ophídios da Colombia. Mem. Inst. Butantan 9: 219-223.

Bonnaterre, P.-J.

1790. Ophiologie. In Tableau Encyclop. Méthod. Règ. Nat. Chez Panckoucke, Paris, France, 76 pp.

Burger, W. L.

1950. A preliminary study of the subspecies of the jumping viper Bothrops nummifer. Bull. Chicago Acad. Sci. 9: 59-67.

1971. Genera of pitvipers (Serpentes: Crotalidae). Unpublished Ph.D. diss., Univ. Kansas, Lawrence, 186 pp.

Campbell, J. A., and W. W. Lamar

1989. The venomous reptiles of Latin America. Ithaca NY: Cornell Univ. Press, 425 pp.

1992. Taxonomic status of miscellaneous Neotropical viperids, with the description of a new genus. Occas. Pap. Mus. Texas Tech Univ. 153: 1-31.

Crother, B. I., J. A. Campbell, and D. M. Hillis

1992. Phylogeny and historical biogeography of the palm-pitvipers, genus Bothriechis: biochemical and morphological evidence. In J. A. Campbell and E. D. Brodie, Jr. (eds.), Biology of the pitvipers: 1-20. Tyler TX: Selva. 
Dixon, J. R.

1979. Origin and distribution of reptiles in lowland tropical rainforests of South America. In W. E. Duellman (ed.), The South American herpetofauna: its origin, evolution, and dispersal: 217-240. Univ. Kansas Mus. Nat. Hist. Monogr. 7.

Dowling, H. G.

1951. A proposed standard system of counting ventrals in snakes. Br. J. Herpetol. 1: 97-99.

Dowling, H. G., and J. M. Savage

1960. A guide to the snake hemipenis: a survey of basic structure and systematic characteristics. Zoologica 45: 17-31.

Freire-Lascano, A.

1991. Dos nuevas especies de Bothrops en el Ecuador. Publ. Trab. Científicos del Ecuador. Univ. Técnica de Machala, 11 pp.

García, E.

1896. Los ofidios venenosos del Cauca. Métodos empíricos y racionales empleados contra los accidentes producidos por la mordedura de esos reptiles. Cali, Colombia: Librería Colombiana, 102 pp.

Golay, P., H. M. Smith, D. G. Broadley, J. R. Dixon, C. J. McCarthy, J.-C. Rage, B. Schätti, and M. Toriba

1993. Endoglyphs and other major venomous snakes of the world. A checklist. Geneva: Azemiops, 478 pp.

Gutberlet, R. L., Jr.

1998a. The phylogenetic position of the Mexican black-tailed pitviper (Squamata: Viperidae: Crotalinae). Herpetologica 54: 184-206.

1998b. Phylogenetic relationships of New World pitvipers (Squamata: Crotalinae) as inferred from gross anatomy, epidermal microstructure, and mitochondrial DNA. Unpublished Ph.D. diss., Univ. of Texas, Arlington.

Gutberlet, R. L., Jr., and M. B. Harvey

1998. Comment on the proposed conservation of the specific and subspecific names of Trigonocephalus pulcher $\mathrm{Pe}$ ters, 1862 and Bothrops albocarinatus Shreve, 1934 (Reptilia, Serpentes) by the designation of a neotype for $T$. pulcher. Bull. Zool. Nomencl. 55: 2932.

In press. Phylogenetic relationships of New World pitvipers as inferred from anatomical evidence. In G. W. Schuett, M. Höggren, and H. W. Greene (eds.), Bi- ology of the vipers. Carmel IN: Biological Sciences Press.

Hennig, W.

1966. Phylogenetic systematics. Chicago: Univ. Illinois Press, 263 pp.

International Commission on Zoological Nomenclature

1999. Opinion 1939. Trigonocephalus pulcher Peters, 1862 (currently Bothrops pulcher, Bothriechis pulcher or Bothriopsis pulchra; Reptilia, Serpentes): defined by the holotype, and not a neotype; Bothrops campbelli Freire Lascano, 1991: specific name placed on the official list. Bull. Zool. Nomencl. 56: 218-220.

Klauber, L. M.

1972. Rattlesnakes: their habits, life histories, and influence on mankind, 2nd ed., 2 vols. Berkeley: Univ. California Press, $1533 \mathrm{pp}$.

Kluge, A. G.

1991. Boine snake phylogeny and research cycles. Misc. Publ. Mus. Zool. Univ. Michigan 178: 1-58.

Kraus, F., D. G. Mink, and W. M. Brown

1996. Crotaline intergeneric relationships based on mitochondrial DNA sequence data. Copeia 1996: 763-773.

Kuch, U.

1997. Comment on the proposed conservation of the specific and subspecific names of Trigonocephalus pulcher $\mathrm{Pe}-$ ters, 1862 and Bothrops albocarinatus Shreve, 1934 (Reptilia, Serpentes) by the designation of a neotype for $T$. pulcher. Bull. Zool. Nomencl. 54: 245249.

McDiarmid, R. W., J. A. Campbell, and T. A. Touré

1999. Snake species of the world: a taxonomic and geographic reference. Vol. 1. Washington DC: The Herpetologists' League, $511 \mathrm{pp}$.

Myers, C. W., J. W. Daly, and B. Malkin

1978. A dangerously toxic new frog (Phyllobates) used by Emberá Indians of western Colombia, with discussion of blowgun fabrication and dart poisoning. Bull. Am. Mus. Nat. Hist. 161: 309365.

Nicéforo-María, H.

1975. Contribución al estudio de las serpientes de Colombia II. Bol. Inst. La Salle (Bogotá) 215: 1-4.

Parkinson, C. L.

1999. Molecular systematics and biogeographical history of pitvipers as deter- 
mined by mitochondrial ribosomal DNA sequences. Copeia 1999: 576586.

Parkinson, C. L., J. A. Campbell, and P. T. Chippindale

In press. Multigene phylogenetic analyses of pitvipers with comments on the biogeographical history of the group. In G. W. Schuett, M. Höggren, and H. W. Greene (eds.), Biology of the vipers. Carmel IN: Biological Sciences Press.

Pérez-Santos, C., and A. G. Moreno

1988. Ofidios de Colombia. Torino: Museo Regionale di Scienze Naturali, 576 pp.

Peters, W. C. H.

1862. Ueber die craniologischen Verschiedenheiten der Grubenottern (Trigonocephali) und ueber eine neue Art der Gattung Bothriechis. Monatsber. Preuss. Akad. Wiss. Berlin 1862: 670674.

Salomão, M. de Graça, W. Wüster, R. S. Thorpe, J.-M. Touzet, and Butantan-British Bothrops Systematics Project

1997. DNA evolution of South American pitvipers of the genus Bothrops. In R. S. Thorpe, W. Wüster, and A. Malhotra (eds.), Venomous snakes: ecology, evolution, and snakebite. Symposia of the Zoological Society of London: 89-98. Oxford: Clarendon Press.

Schätti, B., and E. Kramer

1993. Ecuadorianische grubenottern der gattungen Bothriechis, Bothrops, and Porthidium (Serpentes: Viperidae). Rev. Suisse Zool. 100: 235-278.

Schätti, B., and H. M. Smith

1997. Proposed conservation of the specific and subspecific names of Trigonocephalus pulcher Peters, 1862 and Bothrops albocarinatus Shreve, 1934 (Reptilia, Serpentes) by the designation of a neotype for T. pulcher. Bull. Zool. Nomencl. 54: 35-38.

Shreve, B.

1934. Notes on Ecuadorian snakes. Occas. Pap. Boston Soc. Nat. Hist. 8: 125-132. Vázquez de Kartzow, A. R.

1995. Mordedura de Serpientes Venenosas. Bogotá, Colombia: Ediciones Rosaristas, $114 \mathrm{pp}$.
Vidal, N., and G. Lecointre

1998. Weighting and congruence: a case study based on three mitochondrial genes in pitvipers. Mol. Phylogen. Evol. 9: 366-374.

Vidal, N., G. Lecointre, J. C. Vié, and J. P. Gasc

1997. Molecular systematics of pitvipers: Paraphyly of the Bothrops complex. C. R. Acad. Sci. Paris, Sci. vie 320: 95101.

Werman, S. D.

1984. Taxonomic comments on the Costa Rican pit viper, Bothrops picadoi (Dunn). J. Herpetol. 18: 207-210.

1992. Phylogenetic relationships of Central and South American pitvipers of the genus Bothrops (sensu lato): cladistic analyses of biochemical and anatomical characters. In J. A. Campbell and E. D. Brodie, Jr. (eds.), Biology of the Pitvipers: 21-41. Tyler TX: Selva.

1999. Molecular phylogenetics and morphological evolution in Neotropical pitvipers: an evaluation of mitochondrial DNA sequence information and the comparative morphology of the cranium and palatomaxillary arch. Kaupia 8 : 113-126.

Werman, S. D., B. I. Crother, and M. E. White

1999. Phylogeny of some Middle American pitvipers based on a cladistic analysis of mitochondrial $12 \mathrm{~S}$ and $16 \mathrm{~S}$ DNA sequence information. Contemp. Herpetol. 1999(3): pages unnumbered.

Wüster, W.

1998. Comment on the proposed conservation of the specific and subspecific names of Trigonocephalus pulcher $\mathrm{Pe}-$ ters, 1862 and Bothrops albocarinatus Shreve, 1934 (Reptilia, Serpentes) by the designation of a neotype for $T$. pulcher. Bull. Zool. Nomencl. 55: 3436.

Zamudio, K. R., and H. W. Greene

1997. Phylogeography of the bushmaster (Lachesis muta: Viperidae): implications for Neotropical biogeography, systematics, and conservation. Biol. J. Linn. Soc. 62: 421-442. 


\section{APPENDIX \\ BOTHROCOPHIAS SPECIMENS EXAMINED}

Specimens examined for this study are housed in the American Museum of Natural History (AMNH), California Academy of Science (CAS), Carnegie Museum of Natural History (CM), Field Museum of Natural History (FMNH), United States National Museum (USNM), University of Kansas Museum of Natural History (KU), and The University of Texas at Arlington (UTA).

Bothrocophias campbelli-ECUADOR: El Oro, S of Chonta, 1370 m (AMNH 22094); Pichincha: Pacto (USNM 165322), Mindo (USNM 165340).

Bothrocophias hyoprora-COLOMBIA: Amazonas: Leticia (FMNH 83079); Santa Rosa de los Kofanes, Río Guamues (FMNH 165849); Putumayo Puesto de Guamez, 1000 m (KU 140418); Vaupés, Wacará (UTA R-3768). ECUADOR: Napo, Galeras, at foot of Mt. Sumaco (USNM 165311), Loreto (USNM165313); Oriente: near Canelos, Río Pas- taza, 600 m (FMNH 27597); Pastaza: Río Corrientes (USNM 165297, 165299); mouth of Río Capahuari (USNM 165301); Río Conambo, mouth of Río Shione (USNM 165302); Río Copataza (USNM 165309); Río Oglán, Alto Curaray (FMNH 197880, USNM 165307). PERU: Loreto: San Jacinto, $175 \mathrm{~m}$ (KU 222208); $1.5 \mathrm{~km} \mathrm{~N} \mathrm{Te-}$ niente López, 310 m (KU 222209); Cerro Azul (FMNH 56171).

Bothrocophias microphthalmus-ECUADOR: Zamora (UTA R-23530); PERU: Madre de Dios: Candamo (FMNH 40242); Buena Vista, Valley of the Chimchao (FMNH 5580); San Martín: Cordillera Oriental above Tarapoto (KU 209540); 20 km NE Tarapoto, $990 \mathrm{~m}$ (KU 211621); no other data (FMNH 63740).

Bothrocophias myersi-COLOMBIA: Cauca (AMNH 107919-20, 109812); Valle del Cauca (FMNH 165586-96, USNM 151708, 154051, UTA R-21689). 
Recent issues of the Novitates may be purchased from the Museum. Lists of back issues of the Novitates and Bulletin published during the last five years are available at World Wide Web site http://nimidi.amnh.org. Or address mail orders to: American Museum of Natural History Library, Central Park West at 79th St., New York, NY 10024. TEL: (212) 769-5545. FAX: (212) 7695009. E-MAIL: scipubs@amnh.org 